\title{
INNOVATIVE SOLUTIONS IN CONSTRUCTION INDUSTRY. REVIEW OF 2016-2018 EVENTS AND TRENDS
}

\author{
Oleg KAPLIŃSKI ${ }^{*}$ \\ Faculty of Architecture (IAP), Poznan University of Technology, 60-965 Poznan, Nieszawska 13c, Poland
}

Received 28 January 2018; accepted 21 March 2018

\begin{abstract}
The paper presents an overview of innovative solutions in Construction Industry (CI) between 2016 and 2018. Trends in events within CI were compiled mainly on the basis of reports, to a large extent originating from the US market. Directions and conditions of development of CI (in terms of design, technology and socio-economic sense) are considered. The importance of issues related to digitization, integrated activities (from integrated management to the integrated BIM), and partly augmented reality were highlighted. An attempt to synthesize new instruments in Construction Management has been presented.
\end{abstract}

Keywords: construction innovations, construction industry, trends, review.

\section{Introduction}

Innovation, modern approach, inspiration, changes are leitmotifs which shape economic reality. Innovations are needed for the subject inspiring these changes while preserving the interest of the environment. The aim is (consciously or subconsciously) for the changes to be consistent with the paradigms of sustainable development.

The specific character of Construction Industry ranges wide: from design solutions, technological and technical and economic solutions, decision-making methods, through to organizational solutions and efficient management. From a company point of view there are three basic types of innovation: through research and development $(\mathrm{R} \& \mathrm{D})$, purchase of know-how, acquisition of the so-called material technologies (innovative structures, machines, materials).

The paper deals with the first group of issues, with emphasis on solutions in the field of Construction Management. The text it does not cover issues such as risk of innovation, competition, indicating only the characteristic trends in the development of innovation in Construction Industry.

Construction industry has always been a subject of interest not only for businessmen but for different institutions, too (c.f., Czarnecki et al., 2017a, 2017b; Kanapeckiene, Kaklauskas, Zavadskas, \& Seniut, 2010; Kapliński \& Zavadskas, 2002; Kapliński, Werner, Kosecki, Biernacki, \& Kuczmarski, 2002; Kapliński, Dziadosz, \& Zioberski, 2011; Kapliński \& Zavadskas, 2002). There have been many re- ports and although they differ, trends in progress of technology, methods, organization, etc can be noticed. Most popular and most often read are those reports and portals which are based on information from the US market (e.g., Kapliński, 2017).

The overview of the main trends is the subject of this paper.

\section{Forecasts for 2016}

The American portal ForConstructionPros.com publishes 10 construction trends shaping the industry in 2016 and beyond (ForConstructionPros, 2016). Two problem groups (trends) can be distinguished, i.e. from modelling, 3D printing, and above all, smart buildings, through to BIM supported work organization and safety. It has been synthetically shown in Figure 1. Each of the ten trends includes the author's comments below, characterizing a given trend.

It is worth noting that some of the other trends for 2016 are shown by Peiffer (2016a).

\section{Trends for 2017}

Phenomena and trends presented above (see Figure 1) are going to reach Europe with certain latency. The 2016 accounts have not been "done" yet, and American econo-

${ }^{*}$ Corresponding author. E-mail: oleg.kaplinski@put.poznan.pl 


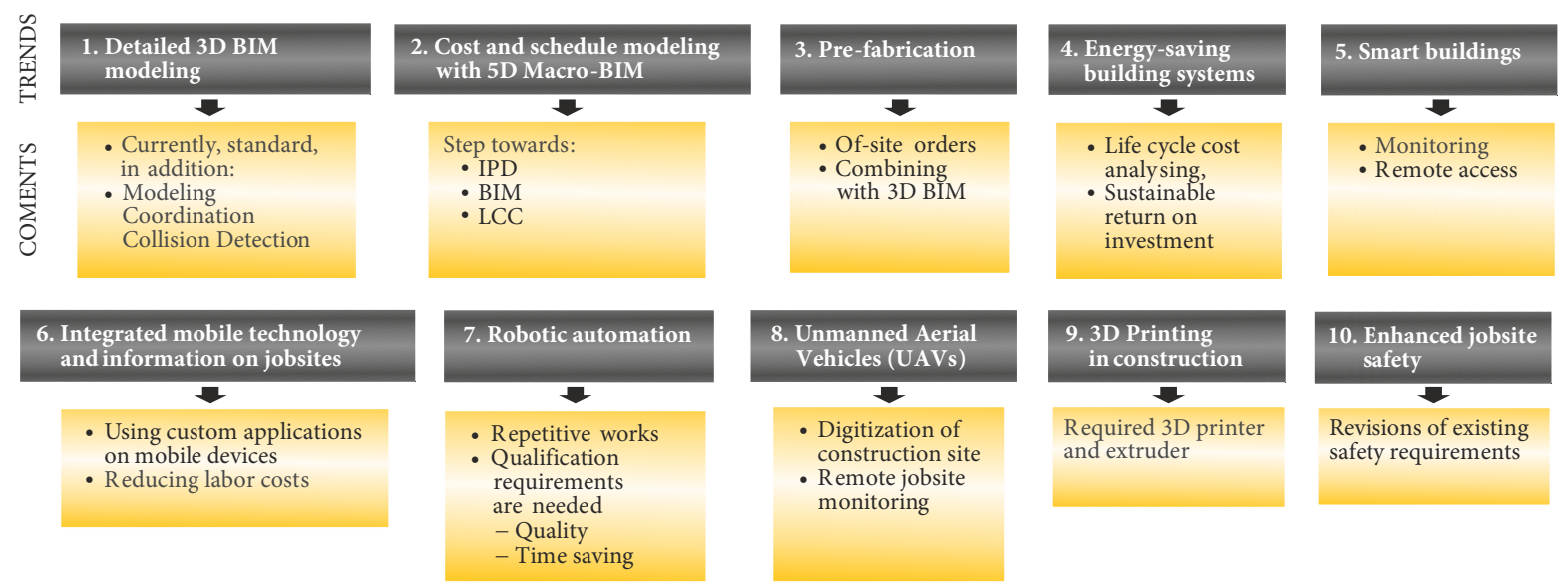

Figure 1. Ten construction trends shaping the industry in 2016 and beyond

mists already predict increased spending on construction industry in 2017 by $5 \%$ compared to last year. However, there is a new phenomenon, i.e. increased uncertainty caused by changes in the central government - after the election of the new president.

Quite a credible report from Dodge Data \& Analytics indicates the following ten trends 2017 (Dodge MarketShare $^{\mathrm{Tm}}$, 2017; Peiffer, 2017, see also SmartMarket Report, 2017; Lindsay, 2015).

- There are forms of organization of the investment process which will consolidate. Design-bid-Build system will be of marginal significance. Two ways of practical implementation of an investment will consolidate, i.e. Design and build and P3 system (PublicPrivate Partnerships). These two systems of practical implementation of an investment have been favoured by the US market for many years. The third system, which will consolidate in the market is integrated designing, after modifications called Integrated Project Delivery (IPD).

- Shortage of manpower in the construction industry will be the weakest link. The crisis in the construction industry from ten years is still lingering. The report indicates that from April 2006 to January 2011, the construction industry lost $40 \%$ of its workforce. Inadequate condition of vocational education is emphasized. Nonetheless, it is still an attractive, well paid job.

- There is a sense of insecurity, primarily among contractors, related to potential changes in legislation, taxation and employment policies. The uncertainty is the result of an imbalance between the new government administration and construction industry. The lack of balance is, nevertheless, not going to affect the 2018 results.

- Modular and prefabricated structures, although they are nothing new, nonetheless will gain a stronger position in the market. This trend continues from the previous period and is caused by the need for quality, with the view to shortening lead times and introducing proper discipline to work organization.
- The announcement of increased spending on infrastructure, which is clear from the election campaign. The emphasis is on reconstruction of existing infrastructure as well as financing under P3. Companies regard this announcement with limited optimism.

- Information technologies. Almost revolutionary solutions regarding jobs are expected to transpire as the result of digitization and artificial intelligence. Such systems as IoT (Internet of Things) and Business Intelligence are going to dominate. Everything is geared towards planning and taking decisions in real time. The construction industry is still influenced by new technologies.

- Increase in prices of building materials and labour cost. A significant jump in prices of materials is expected, but companies are going to keep margins at the current level. Because of the shortage of skilled workers, the average salary will increase (higher than the national average, anyway).

- Increase the importance of VR and AR, or else Virtual and Augmented Reality technologies. Virtual and extended space of activity, particularly useful in the stages of design, management and organization of the building site itself. Companies envisage training in this area, even on an international scale. The following benefits, among others, are mentioned: detecting errors in advance, avoiding costs of mistakes, detecting safety risks, monitoring work sites.

- Strengthening of the trend which, in the near future, will make sustainable construction more a norm than an exception. Indirectly, it is the matter of reduction of energy costs and creating jobs. This trend is expected to continue, despite the attitude of uncertainty towards the current administration.

- The trend to respect the workplace, prevalent in the previous period, is going to continue. This trend is multi-faceted, as it ranges from fair invoicing of works performed to high penalties for accidents at the building site. 


\section{New developments for $\mathbf{2 0 1 8}$}

Forecasts for 2018 do not differ significantly from forecasts for previous years. Based on publications of several authors and research institutions (Akbar, 2017; Claire, 2017; Jones, 2018; Menard, 2018; Slowey, March, \& Cowin, 2018; Tiltwall Ontario Inc., 2018) the following conclusions can be drawn:

- the trends may be stronger

- labour force shortages,

- the interest in prefab and modular construction continues to grow,

- hopes for solving problems related to labour, safety and productivity thanks to new technological solutions are growing.

In addition, the importance of the triangle BIM VR - Green Construction relationship is accentuated (Akbar, 2017).

DConstuctionDIVE (USA) according to the Dodge Data \& Analytics research (Slowey et al., 2018) indicates growing dependence (and hopes) on technology, and after the failures in 2017 (market fluctuations, unexpected events), advocates resiliency and management flexibility.

Canadian company Tiltwall Ontario Inc. (2018) and Californian SKYSITE (2017) clearly point to: various dimensions of BIM, including 4D (time), 5D (cost), 6D (as-built operation), 7D (sustainability), 8D (safety); Augmented Reality; Robotics \& Exoskeletons; IoT; Drones; Cloud Computing; Mobile Field Software; AI; Smart Buildings; and even on Self-Driving Vehicles. All these solutions will influence construction industry, but a new context also appears: it is about making life easier for us.

\section{Structural, technical and socio-economic aspects}

Without structural and technical solutions (including technical equipment in the building) construction itself can not be considered. You can look even wider, i.e. through paradigms of sustainable development. There are many interesting sites, reports that present data from rapidly emerging markets. The Chinese market is a good example.

Special Innovation Awards are granted. Unfortunately, prizes are not awarded for overall (A-Z) solutions, but for individual elements in the building (e.g., for elevations), design methods, and ways of practical implementation.

Not all interesting ideas are published. Some solutions are limited by patent claims.

An example of recent awards in the area of "Innovations in high-rise building design" is provided in (Building Design+Construction, 2016; CTBUH and BD+C STAFF, 2015).

A European Union Report (Probst, Monfardini, Frideres, \& Cedola, 2014) commenting on Smart construction products and processes pays close attention to socio-economic relevance, including demographical change, environmental factor, better quality of life. Commenting on socio-economic issues in the smart context is very brave, solutions are sought for in three areas:

- The creation of new markets and jobs,

- Bringing smarter construction processes and products to the market,

- Client perspectives and challenges related to the uptake of smart construction technologies, including two aspects:

- Knowledge challenges: (lack of awareness by builders of the new advancements available in the field of construction results in poor execution of constructions),

- Risk avoidance challenges (this is related to the large amounts of capital invested).

\section{A look at the Summit of the Americas}

The interesting RICS Forum (The Summit of the Americas), in conjunction with The World Built Environment Forum (WBEF) was held in April 2016 in Washington.

A number of issues were debated which, as it turns out, are characteristic not only for American builders, but also for other areas of the world. Three trends can be identified clearly among them (Peiffer, 2016b).

The first one is related to selection and analysis of a mass of information, in other words, BIG DATA. One of the basic elements of the spatial modeller - e.g. Autodesk. The motto of this trend is not only the modelling of different cases, but also use of the information in budgeting and scheduling. The information is stored in the cloud, and drones are also used to acquire information.

The second trend concerns durability of the building, impact on the environment, the value of the assets life cycle (including operating costs) which, in a nutshell, can be described as "high-performing buildings". Engineers there realize that the cost of construction itself is a small percentage of the total cost of the building's life. The cost of maintaining the building over 30 years is a multiple of the cost of its construction. However, it was stressed that a tall building is more efficient to operate and use because the impact of the ongoing costs of maintenance and repairs decreases.

The third trend concerns the agreements and partnerships, and therefore applies to legislation (contracts) and organizations (cooperation). The importance of publicprivate partnership (P3) is constantly growing. Despite technological innovation being introduces in construction industry, the significance of a formal contract is unchanged. However, its scope must be adapted to new requirements. It is emphasized that organization of the investment process according to $\mathrm{P} 3$ requires specific managerial knowledge.

\section{Towards Augmented Realty}

Basing on surveys published in 2016 (Jackson, 2016; Peiffer, 2016a, 2016b) some conclusions can be drawn as to factors which will have a significant impact on design and 
implementation in the near future. They are as follows (short explanations are given in parentheses):

1. Building information modelling

2. Robots

3. Visualisation and virtual reality

4. Internet of things (IoT, connection with BIG DATA). See the comments in (Kapliński, Košeleva, \& Ropaite, 2016)

5. Lockable composite road plates (for quick repairs of road surface)

6. Aerogel (ultra-light, synthetic porous material - as thermal insulation)

7. Drones

8. 3D printing and digital off-site manufacturing

9. MassMotion (change of transport infrastructure, adaptation to the changing needs of the mass of passengers, new requirements in terms of software, the use of artificial intelligence)

10. SoundLab (not just noise problems but also communication through sounds)

It is worth noting that the benefit from the application of these factors will rank higher when they are taken into consideration already at the stage of preliminary design.

These are material, technological and organizational solutions already included within the scope of augmented realty (AR), or a system that connects the real world with computer-generated reality. A year earlier, Raconteur platform presented trends/innovations (Jackson, 2015) whose synthesis is shown in Figure 2. Three out of the ten innovations: cloud collaboration, asset mapping and predictive software confirmed the observation regarding AR. The kinetic roads innovation should be understood as converting kinetic energy into electrical energy produced by moving vehicles.

The trend in the development of Augmented Realty continues. This is evident in several forecasts for 2018: Akbar, 2017; Slowey et al., 2018; Tiltwall Ontario Inc., 2018.

\section{An attempt of a synthesis}

Is it possible to make a résumé of these trends? Their comparison is not even desirable, because they relate to very different aspects, i.e. from design and technology of construction to the economic issues. Below is an attempt of a synthesis but in the area of construction management.

This synthesis uses earlier individual own research (Kapliński, 2008, 2009, 2015; Kapliński \& Peldschus,
2011) and team research: Gajzler (2016), Dziadosz, Tomczyk, and Kapliński (2015), Dziadosz and Kończak (2016), Kalibatas, Kalibatiené, and Kapliński (2018), Turskis, Gajzler, and Dziadosz (2012), Zavadskas, Turskis, and Tamošaitiene (2008), Zima and Leśniak (2013).

In order to discuss technology and management tools in the construction industry (CI), one should refer to the eighties, when Manufacturing Resource Planning program, and later Enterprise Resource Planning began to be implemented in construction industry. From that moment Production Resources Planning really begun. Currently, we are witnessing another breakthrough which is called Augmented Reality (AR). It is a system which combines the real world with computer-generated reality. AR elements are shown in Figure 3. An inspiration for such graphic form was a World Economic Forum report, Committed to Improving the State of the Word, published in 2016: World Economic Forum (2016). Figure 3 is an attempt to indicate the rank and importance on new technologies - in the impact-likelihood setting, however, it does not coincide with the matrix presented in (World Economic Forum, 2016).

The range of $\mathrm{AR}$ in the area of CI covers, e.g. systems of wireless monitoring systems (including specific implementations, technology, safety, costs, and control of production). Large group of issues is formed by the Integrated IT systems. There is, for example, Integrated Management, Integrated Project Delivery (IPD), Integrated BIM so important today and BLM (Building Life Cycle Management), IoT (Internet of Things), Case-Base Reasoning and other. Of course, in the future, we will not be ale to do without BIG DATA (analysis) and cloud.

What is becoming important is correct organizational factors such as: Real-time mobile collaboration. In order for those factors and trends to be effectively implemented, legislative conditions must come to existence. Also, work must proceed in favourable structures, i.e. in systems of organization and realization of investments, including P3 system, so cherished in the American market.

The issues of the structure life cycle have been placed on the right side as Life-Cycle Cost Analysis (LCCA). It is the synergy of other items listed in the drawing and described in the preceding paragraphs. It brings together not only operating costs, but also the issues of energy efficiency and sustainable development. The need to implement LCCA in the EU follows up the EU Directive (Directive 2010/31/EU).

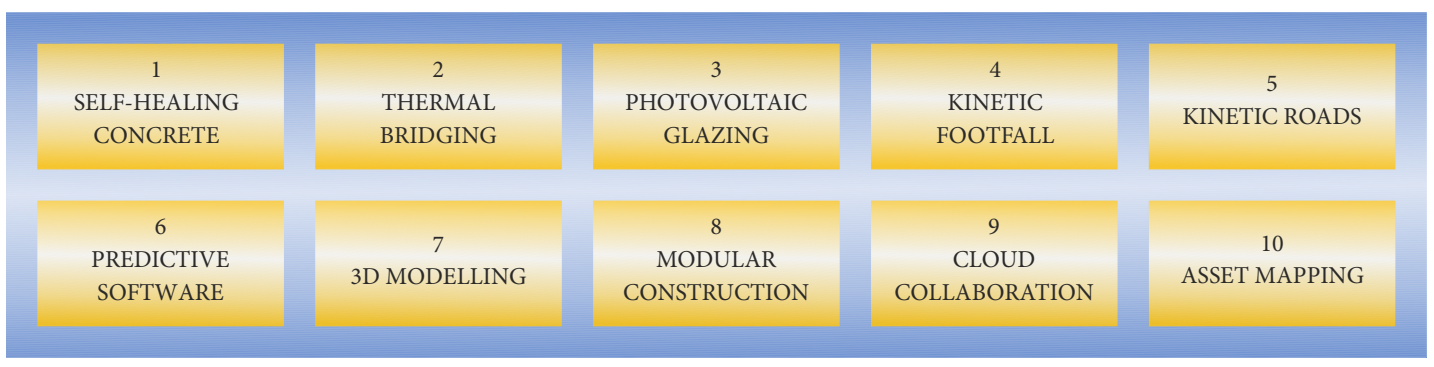

Figure 2. Innovations taking into account the augmented realty 


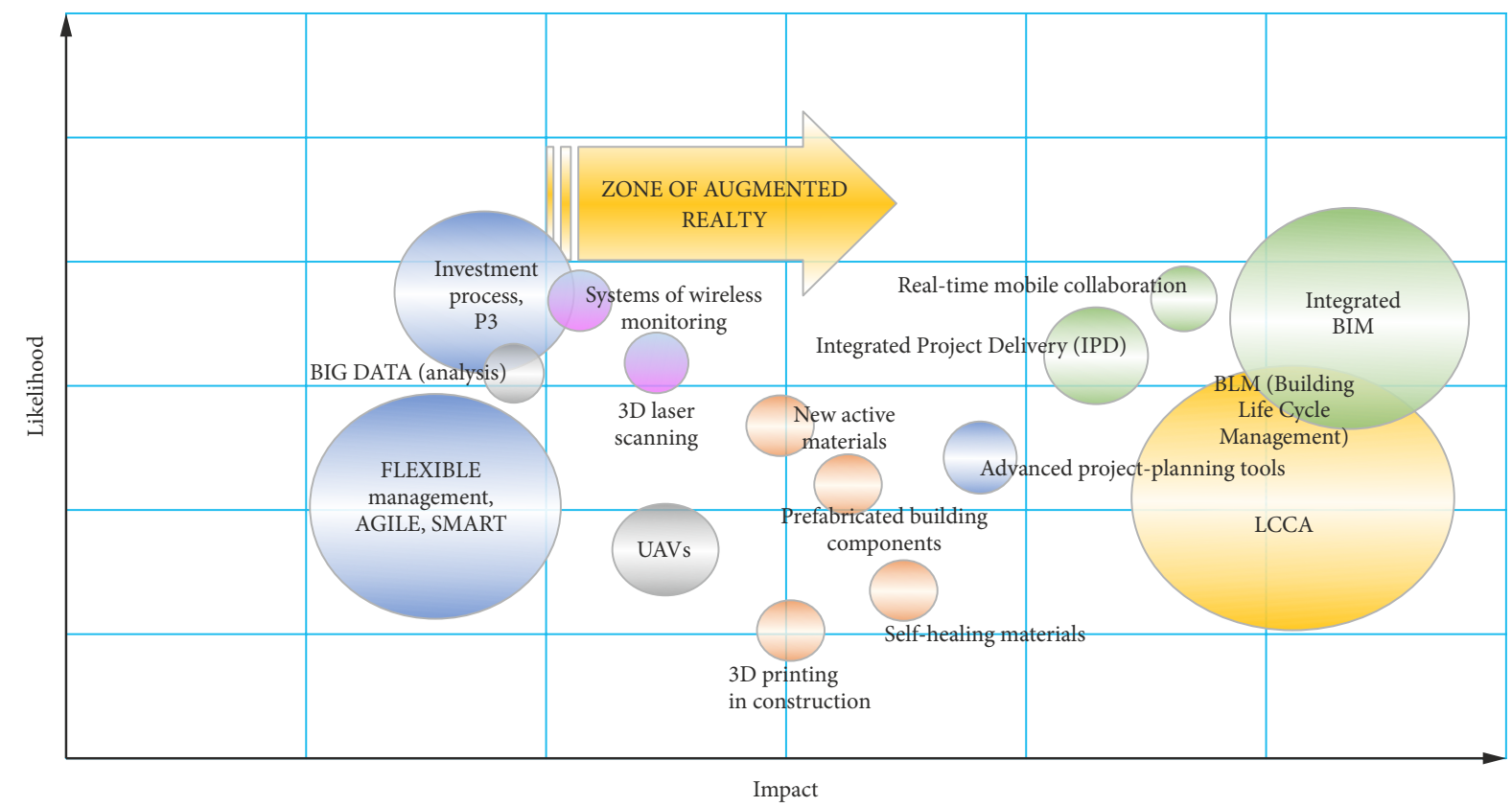

Figure 3. An attempt to identify rank and importance of new technologies in Construction Management - in the impact-likelihood setting

\section{Commercialization of innovative approaches - trends in Construction Industry}

Reviewing commercialization of innovative approaches in $\mathrm{CI}$ it is obvious that changes are exciting but they require money and knowledge. What does the commercial US market offer to developers and users? Companies operate on the basis of commercial law and are not limited to consulting (offering the "key to success") but also to the foundations of education. Based on the Nationwide Construction (blog) companies' most spectacular achievements are in the following areas (Nationwide Construction, 2016):

- Renewable Energy and Sustainability, including solar installations, heating and cooling layouts, sustainable building materials. All solutions sell well,

- Virtual and Augmented Reality Modelling, within this area - new ways to model and visualize a property or renovation project, sophisticated digital models. Today, it is a commercial determinant of a company,

- Prefabricated Commercial Construction, including advertising streamlining the process of construction, to be completed faster, better security and performance is offered,

- Integrated Mobile Technology and Smart Buildings. Many buyers are surprised by the range of options in automation and control of a building. Three solutions have the greatest demand: On-site security and access, Climate control and regulation, On-site communications.

- Three Dimensional Printing: a possibility of using curved forms in contrast to conventional limitations, i.e. rectilinear forms (limiting the architecture of the completed building).
In all cases, a reduction in costs through automation and digitization is offered.

Large companies (corporations) innovate more than small and medium-sized ones. This stems mostly from the fact that they have already invested in innovation-oriented solutions, and do not want to lose their position in the competitive market (see also Claire, 2017; Jones, 2018).

\section{Conclusions}

Innovation associates (and rightly so) with a dynamic economic development. The attributes are: competitiveness, utility of solutions, strategies of change.

Construction Industry (CI) solutions form a range extending in different directions. Material and technological/hardware trends are universal. Special emphasis is put on integrated actions, for example, Integrated Management, Integrated Project Delivery (IPD), Systems of wireless monitoring, IoT (Internet of Things), Case-Base Reasoning, BLM (Building Life Cycle Management), Integrated BIM.

The power of innovation requires a suitable substrate. These are legislative and organizational matters. Economic relationships also play a significant role. In developed countries, in CI, a D-B-O (Design-Build-Operate) type system of organization has taken root, corresponding to the requirements of P3 system (Public-Private Partnerships). The quoted reports emphasize that $\mathrm{P} 3$ type of investment process organization is the most preferred in innovative speculations.

All presented trends either directly (e.g., green buildings) or indirectly affect sustainable development.

It is felt that security issues are important requirements for innovation. Experts voice concern about the lack of staff and its training. 


\section{References}

Akbar, S. (2017). Top 8 construction trends for 2018. Retrieved from https://geniebelt.com/blog/top-8-trends-for-construction-in-2018?utm_referrer=https\%3A\%2F\%2Fwww.google. $\mathrm{pl} \% 2 \mathrm{~F}$

Building Design+Construction (Digital ed.). (2016). Retrieved from https://www.bdcnetwork.com/current-issue

Claire, E. (2017). Top five construction industry trends for 2018: From technology to safety. Retrieved from http://www.lorman. com/resources/top-five-construction-industry-trends-for2018-from-technology-to-safety-16578

CTBUH and BD+C STAFF. (2015). 5 innovations in high-rise building design. Retrieved from https://www.bdcnetwork. com/5-innovations-high-rise-building-design

Czarnecki, L., Deja, J., Furtak, K., Halicka, A., Kapliński, O., Kaszyńska, M., Kruk, M., Kuczyński, K., Szczechowiak, E., \& Śliwiński, J. (2017a). Idee kształtujące innowacyjne wyzwania techniki budowlanej. Kierunki rozwoju. Materiały Budowlane, 7, 34-39.

Czarnecki, L., Deja, J., Furtak, K., Halicka, A., Kapliński, O., Kaszyńska, M., Kruk, M., Kuczyński, K., Szczechowiak, E., \& Śliwiński, J. (2017b). Idee kształtujące innowacyjne wyzwania techniki budowlanej. W poszukiwaniu paradygmatu rozwoju budownictwa. Materiały Budowlane, 7, 28-33.

Dodge MarketShare ${ }^{\mathrm{Tw}}$. (2017). Construction industry trends. Retrieved from http://www.construction.com/dodge/marketshare.asp

Dziadosz, A., \& Kończak, A. (2016). Review of selected methods of supporting decision-making process in the construction industry. Archives of Civil Engineering, 62(1), 111-126. https://doi.org/10.1515/ace-2015-0055

Dziadosz, A., Tomczyk, A., \& Kapliński, O. (2015). Financial risk estimation in construction contracts. Procedia Engineering, 122, 120-128. https://doi.org/10.1016/j.proeng.2015.10.015

ForConstructionPros. (2016). 10 construction trends shaping the industry in 2016 and beyond. Retrieved from http://www. forconstructionpros.com/article/12162200/10-constructiontrends-shaping-the-industry-in-2016-and-beyond

Gajzler, M. (2016). Usefulness of mining methods in knowledge source analysis in the construction industry. Archives of Civil Engineering, 62(1), 127-142.

https://doi.org/10.1515/ace-2015-0056

Jackson, F. (2015). Top ten construction innovations. Retrieved from http://raconteur.net/business/top-ten-constructioninnovations

Jackson, F. (2016). Ten ways we are changing the way we build. Retrieved from http://raconteur.net/business/ten-ways-weare-changing-the-way-we-build

Jones, K. (2018). 5 commercial construction trends to watch in 2018. Retrieved from https://www.constructconnect.com/ blog/construction-news/5-commercial-construction-trendswatch-2018/

Kalibatas, D., Kalibatienè, D., \& Kapliński, O. (2018). A systematic review of information modelling of individual residential buildings. Engineering Structures and Technologies (in printing).

Kanapeckiene, L., Kaklauskas, A., Zavadskas, E. K., \& Seniut, M. (2010). Integrated knowledge management model and system for construction projects. Engineering Applications of Artificial Intelligence, 23(7), 1200-1215.

https://doi.org/10.1016/j.engappai.2010.01.030
Kapliński, O. (2009). Information technology in the development of the Polish construction industry. Technological and Economic Development of Economy, 15(3), 437-452.

https://doi.org/10.3846/1392-8619.2009.15.437-452

Kapliński, O., \& Peldschus, F. (2011). The problems of quantitative evaluation of socio-economic systems' development (Review). Engineering Economics, 22(4), 345-355.

https://doi.org/10.5755/j01.ee.22.4.710

Kapliński, O. (2008, February). Advancement in construction management tools: the Polish experience. In P. J. Rao, V. Ramakrishnan, I. Patnaikuni \& V. S. Parameswaran (Eds.), Proceedings of $2^{\text {nd }}$ International Conference on Advances in Concrete and Construction (ICACC-2008), 2, 1210-1218. Ibrahimbach, Hyderabad, India.

Kapliński, O. (2015). Problems of the information technologies use in Polish construction sector: state of the art. Archives of Civil Engineering, 55(2),173-198.

Kapliński, O. (2017). Innowacje i trendy w budownictwie amerykańskim. Materiały Budowlane, 3, 74-76.

https://doi.org/10.15199/33.2017.03.22

Kapliński, O., Dziadosz, A. \& Zioberski , J. L. (2011). Próba standaryzacji procesu zarządzania na etapie planowania i realizacji przedsięwzięć budowlanych. Zeszyty Naukowe Politechniki Rzeszowskiej, Budownictwo i Inżynieria Środowiska, 58(3/11/I), 79-100. Retrieved from https://www.researchgate. net/publication/322099874

Kapliński, O., \& Zavadskas, E. K. (2002). An overview of problems related to the research in construction engineering, management and economics in Poland. Journal of Civil Engineering and Management, 8(4), 231-239. https://doi.org/10.1080/13923730.2002.10531283

Kapliński, O., Košeleva, N., \& Ropaite, G. (2016). Big Data in civil engineering: a state-of-the-art survey. Engineering Structures and Technologies, 8(4), 165-175. https://doi.org/10.3846/2029882X.2016.1257373

Kapliński, O., Werner, W., Kosecki, A., Biernacki, J., \& Kuczmarski, F. (2002). Current state and perspectives of research on construction management and mechanization in Poland. Journal of Civil Engineering and Management, 8(4), 221-230. https://doi.org/10.1080/13923730.2002.10531282

Lindsay, B. (2015). Key trends in the construction industry. Retrieved from https://www.oracle.com/us/assets/key-industrytrends-2773761.pdf

Menard, S. (2018). 6 construction industry trends to expect in 2018. Retrieved from https://esub.com/6-construction-industry-trends-expect-2018/

Nationwide Construction. (2016). Commercial construction company industry: top 5 innovative trends. Retrieved from http:// www.nationwideconstruction.us/commercial-constructioncompany-industry-top-five-trends/

Peiffer, E. (2016a). 10 construction industry trends to watch in 2016. Retrieved from http://www.constructiondive. com/news/10-construction-industry-trends-to-watchin-2016/411402/

Peiffer, E. (2016b). 3 concepts that will shape the future of construction. Retrieved from http://www.constructiondive.com/ news/3-concepts-that-will-shape-the-future-of-construction/417049/

Peiffer, E. (2017). 10 construction industry trends to watch in 2017. Retrieved from http://www.constructiondive.com/ news/construction-industry-trends-2017/433151/ 
Probst, L., Monfardini, E., Frideres, L. \& Cedola, D. (2014, February). Smart construction products and processes. In Business Innovation Observatory. European Union, PwC Luxembourg.

SKYSITE. (2017). Construction trends to watch for in 2018. Retrieved from https://www.skysite.com/construction-trendsto-watch-for-in-2018/

Slowey, K., March, M. T., \& Cowin, L. (2018). 8 construction trends to watch in 2018. Retrieved from https://www.constructiondive.com/news/8-construction-trends-to-watchin-2018/514284/

SmartMarket Report. (2017). The drive toward healthier buildings 2016: tactical intelligence to transform building design and construction. Retrieved from https://www.asid.org/sites/ default/files/images/Documents/Drive-Toward-HealthierBuildings-2016.pdf

Tiltwall Ontario Inc. (2018). Blog \& Company News: 10 technology trends the construction industry should watch in 2018. Retrieved from https://tiltwall.ca/blog/10-technology-trendsthe-construction-industry-should-watch-in-2018/
Turskis, Z., Gajzler, M., \& Dziadosz, A. (2012). Reliability, risk management, and contingency of construction processes and projects. Journal of Civil Engineering and Management, 18(2), 290-298. https://doi.org/10.3846/13923730.2012.672931

World Economic Forum. (2016, May). Shaping the future of construction. A breakthrough in mindset and technology, committed to improving the state of the word (81 p.). Prepared in collaboration with The Boston Consulting Group. Cologny, Geneva.

Zavadskas, E. K., Turskis, Z., \& Tamošaitiene, J. (2008). Contractor selection of construction in a competitive environment. Journal of Business Economics and Management, 9(3), 181187. https://doi.org/10.3846/1611-1699.2008.9.181-187

Zima, K. \& Leśniak, A. (2013). Limitations of cost estimation using building information modeling in Poland. Journal of Civil Engineering and Architecture, 7(5), 545-554. 